\title{
8. Ausztria: 150 éves gyökerek, 21. századi megoldások
}

\author{
CSEMÁNÉ VÁRADI ERIKA
}

\section{A különleges jogrend alkotmányos és törvényi szintü szabályozása}

„A különleges jogrend az alkotmányos szabályozás különös része, a békétől eltérő időszakok joga. Maga a különleges jogrend elnevezés, mint az eltérő definíciós elemeket hordozó időszakok gyứjtőfogalma." ${ }^{1}$ Az osztrák alkotmány, a Bundes-Verfassungsgesetz ${ }^{2}$ a különleges jogrend fogalmát nem írja le, nem tartalmaz átfogó rendelkezéseket annak esetköreire, s nem ad kifejezett hatáskört a kormánynak, a szövetségi elnöknek vagy bármely más szervnek arra, hogy hivatalosan meghatározza a különleges jogrend alkalmazását megalapozó helyzet, így például a válság fennállását. Emellett speciális, a válságkezeléssel kapcsolatos eszközkészlet sem látszik megjelenni ezen a síkon, mint például kijárási tilalom elrendelésének lehetősége a krízisállapottal érintett földrajzi területre.

I Till, 2019, 2. o.

2 Szövetségi alkotmánytörvény (Bundes-Verfassungsgesetz, a továbbiakban: B-VG).

3 „A B-VG [...] nem tartalmaz a válsággal kapcsolatos konkrét eszközöket, például bizonyos érintett személyek számára kijárási tilalom bevezetésének lehetőségét egyes érintett területekre." (Reindl-Krauskopf et al., 2016, 149. o.).

Csemáné Dr. Váradi Erika, PhD, LLM judit.erika.varadi.csemane@mfi.gov.hu vezető kutató (Mádl Ferenc Összehasonlító Jogi Intézet) egyetemi docens (Miskolci Egyetem Állam- és Jogtudományi Kar, Bűnügyi Tudományok Intézete) elnök (Miskolci Egyetem Állam- és Jogtudományi Kar, Alternatív Konfliktuskezelési és Vitarendezési Interdiszciplináris Kutatóközpont)

Csemáné Váradi, E. (2021) 'Ausztria: 150 éves gyökerek, 21. századi megoldások' in Nagy, Z., Horváth, A. (szerk.) A különleges jogrend és nemzeti szabályozási modelljei, 194-216. o. Budapest: Mádl Ferenc Összehasonlító Jogi Intézet.

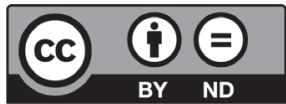


Az osztrák szabályozás hátterében részben a speciális esetkört érintő szabályozástörténeti előzmények, részben az Osztrák Köztársaság szövetségi államszervezete áll.

A különleges jogrendre az alkotmányban minimális utalást találunk. Abban az alkotmányban, amely ma is az 1920-as, alapjogi elemeiben az 1867-es alkotmányt, más vonatkozásokban az 1929-es alkotmánymódosítás elemeit és megoldásait foglalja magában. Az osztrák jogtörténetben megjelenő „kivételes hatalom” egy, az általánostól eltérő speciális helyzet által generált és csak annak fennálltáig múködő, az általánostól eltérő hatalomgyakorlási formát tett lehetővé. Ez azonban - a különleges jogrenddel megegyezően - az adott állam „normális", azaz mindennapi múködése mellett nem volt alkalmazható. Már az 1867-es osztrák állami alaptörvényből ${ }^{4}$ sem mellőzhető két szakasz kiemelése, ha a különleges jogrend hatályos szabályozást magyarázó korai forrásait vizsgáljuk. Ez egyrészt az StGG 14. cikke, amely lehetôvé tette, hogy - kivételes jelleggel, korlátozott esetkörben és mértékben, de - az osztrák birodalmi gyưlés (parlament) ülésezésének hiányában a kormány ideiglenesen törvényi erővel bíró rendeleteket adhasson ki. Másrészt az alaptörvény 20. cikkelye épp az alaptörvénnyel garantált jogok keretek közötti felfüggesztésére adott módot külön törvény (Suspensiongesetz) életre hívásának lehetővé tételével. ${ }^{5}$ Erre szigorú jogszabályi feltételek mellett, meghatározott helyen és időben kerülhetett sor, így például háború, háborús veszély („küszöbön álló háború”), belső nyugtalanság vagy alkotmányos szempontból „fenyegető jellegú tevékenység” esetén. Ezek fennállta mellett az állampolgárok alkotmányban ${ }^{7}$ rögzített jogai korlátozhatóvá, illetve felfüggeszthetővé válhattak (beleértve például az olyan alapjogokat, mint a gyülekezési, az egyesülési jog vagy a sajtószabadság). A 2. világháború után visszaállított 1920/1929-es alkotmány továbbvitelét és a szövetségi elnök kivételes hatalmát nem árnyékolta be az osztrák parlament 1933. márciusi felszámolását követő rendeleti kormányzás. Ennek indoka, hogy az autoriter állam múködésének nem az alkotmány 1929-es - a szövetségi elnök kivételes hatalmát lehetővé tevő - módosítása, hanem a mindvégig hatályban volt gazdasági felhatalmazásról szóló törvény ${ }^{8}$ jelentette a(z jog)elvi-törvényi alapját. "Az egykori alkotmányos jogrendet visszaállítva és a múlt alkotmányjogi vívmányaira építve, valamint az elismert jogtudósok, alkotmányjogászok politikai-alkotmányjogi kérdésekbe történő bevonásának köszönhetően létrejött a demokratikus alapokon múkködő és föderális szerkezetû Második Osztrák Köztársaság."ํㅜ Így a különleges jogrend

4 Staatsgrundgesetz (a továbbiakban: StGG): 1867. december 21-i állami alaptörvény a birodalmi tanácsban képviselt királyságok és országok állampolgárainak általános jogairól (RGBI. Nr. 142/1867).

5 Lásd erről részletesebben: Hinghofer-Szalkay, 2019.

6 Ez utóbbi felölelhette például azokat a nagy nyilvánosságot célzó megmozdulásokat, amelyek akár az állampolgárok személyes biztonságának sérülésével, akár javak elpusztításával fenyegettek.

7 StGG 8-10. és 12-13. cikk.

8 Kriegswirtschaftlichen Ermächtigungsgesetz (KWEG) [Gesetz vom 24. 7. 1917 (RGBl. Nummer 307)]. Bővebben lásd: Staudigl-Ciechowicz, 2018.

9 Lásd errôl részletesebben: Staudigl-Ciechowicz, 2018, 274-293. o.

10 Maróti, 2017, 392-406. o. 
fogalmának és eseteinek meghatározása sem az 1920-as - hatályába visszahelyezett - alkotmánynak, sem az azóta foganatosított módosító novelláknak nem volt tárgya.

Az alkotmány jelenlegi formájában is megőrzi tehát egyrészt azon sajátosságát, hogy számos, a különleges jogrend szempontjából meghatározó releváns kérdést (így például annak fogalmát, esetköreit, az azok kezelését lehetôvé tévő eszközkészletet) a kritikai megjegyzések ellenére nem - vagy nem teljeskörúen - szabályoz. Ugyanakkor a szövetségi elnök rendeleti kormányzását lehetôvé tevő kivételes hatalom megmaradt az alkotmányban. ${ }^{11}$

Nem változott a jogi felfogás a tekintetben sem, hogy a különleges jogrendet megalapozó szituációk jellegük, hatásaik, jelentőségük, kiterjedtségük stb. okán tipikusan - de nem kizárólagosan - szövetségi szinten kerülnek szabályozásra és végrehajtásra ('́gy az egészségüggyel kapcsolatos súlyos helyzetek kezelése), míg például természeti katasztrófák vagy túzvész esetén a tartományok is jogosultak döntést hozni és eljárni. Ugyanakkor az alaptörvényben nevesített válsághelyzetekben ${ }^{12}$ szövetségi szintre tartozik mind a jogalkotás, mind a végrehajtás, például katonai ügyekben vagy olyan intézkedéseknél, amelyek a háború során vagy annak eredményeként, a gazdaság egységes irányításának biztosításához szükségesnek tû́nnek (különös tekintettel a lakosság fogyasztási cikkekkel való ellátására).

Mindezen jog- és szabályozástörténeti előzményekből is eredően a jelenleg hatályos osztrák alkotmány sem tartalmaz rendelkezéseket a különleges jogrend fogalmát - egy kivételével -, esetköreit, reakcióeszközeit illetően. ${ }^{13}$ Ez azt eredményezi, hogy a szakirodalomban fellelhető elemzések szerint a különleges jogrendre vonatkozó normák rendszerezése és tartalma az osztrák jogelmélet oldaláról korántsem kritika nélküli. ${ }^{14}$

Az elméleti munkák ismerik az úgynevezett kvázi különleges jogrend fogalmát is. Ez alatt „olyan válsághelyzeteket értünk, amelyek esetében még nem kell/lehet kihirdetni a különleges jogrendet, azonban a normál jogrendtől eltérő megoldásokat kívánnak, amelyek során a gyakorlatban megvalósul egy-egy alapjog korlátozása, és amikor a kormányzat széles felhatalmazási jogkörökkel rendelkezik (lásd például menekültügyi válsághelyzet, egészségügyi válsághelyzet)". ${ }^{15}$ Minden állam célja a különleges jogrendet megalapozó helyzet kialakulásának megelőzése lenne, azonban ez nehézségbe ütközik: a közelmúlt több krízise is azt mutatta, hogy épp a prevencióra leginkább alkalmas eszkalációs szakaszban az „nem kapcsolható össze a különleges jogrenddel”. Ez Ausztria esetén is problémát jelent.

A szakirodalom szerint a válsághelyzet lehet belső vagy külső eredetú, szövetségi vagy tartományi szintû, katonai vagy civil területet érintő, s jellegét tekintve is igen különböző formát ölthet a zavargásoktól, terrortámadástól a katasztrófa- vagy egészségügyi válság-

11 B-VG 18 cikk (3)-(5) bekezdés.

12 B-VG 10. cikk (1) bekezdés 15. pont.

13 „Az osztrák alkotmány nem tartalmaz semmilyen kifejezett hatáskört a kormány, a szövetségi elnök vagy bármely más testület számára arra vonatkozóan, hogy hivatalosan - szövetségi szinten - meghatározza a válság fennállását." (Reindl-Krauskopf et al., 2016, 148. o.).

14 Koja, 1979.

15 Kelemen, 2019, 13. o. 
helyzeten át a kibertámadásig. Közös bennük, hogy bekövetkeztük esetén a lakosság nagyobb számát érintik, jelentősen veszélyeztetve az állam, a társadalom, az állampolgárok biztonságát. Mindez speciális intézkedéseket és különös múködési szabályokat igényel.

A modern európai alkotmányok már a kezdetektôl fogva ${ }^{16}$ ugyanazon négy nagy területét határozták meg a krízishelyzeteknek, amelyeket a mai legtöbb alkotmány is nevesít:

- a háború mint külső fenyegetettség;

- a belső biztonság fenyegetettsége felkelés vagy lázadás útján;

- természeti események vagy katasztrofális következményekkel járó vis maior esetek;

- egyéb gazdasági, társadalmi vagy humanitárius válságok, amelyek általában ellátási válságok is egyben.

Az osztrák jogelmélet - és így az alkotmányjog is - szintén négy olyan szituációt ismer, amely a különleges jogrendet megalapozó jellemzókkel rendelkezik.

A háborús helyzetre vonatkozóan az alkotmány kimondja, hogy az államvédelem katonai dimenziója mellett a szellemi, polgári és gazdasági értékek is védelmet élveznek. ${ }^{17}$ Továbbá az általános védelmi kötelezettség értelmében háború idején az osztrák állampolgárságú férfiak biztosítják a felfegyverzett polgárőrséget, azaz valamennyi osztrák állampolgár férfi hadköteles, az osztrák női állampolgárok pedig szabad akaratukból katonai szolgálatot teljesíthetnek a szövetségi hadseregben. ${ }^{18} \mathrm{Az}$ alkotmány szerint a szövetségi hadsereg fôparancsnoka a szövetségi elnök. ${ }^{19}$ Ezenkívül az alkotmány megköveteli, hogy a háborús helyzet fennállásáról szóló döntést a szövetségi gyưlés keretein belül hozzák meg - azaz a kormány egyedül nem határozhat erról.

Az állam rendje elleni második klasszikus fenyegetési formát a belső biztonságot támadó cselekmények testesítik meg. Ezeknek tradicionálisan két típusát különböztetik meg: az egyik a legfelsőbb szerv ellen elkövetett támadás, amely a hatalom átvételét célozza, a másik pedig a lázadás és a terror, amelyeknél a fenyegetés és a stabilitás felbomlasztása a cél.

A belső biztonságot fenyegető veszélyekre való reagálást érintő rendelkezés megtalálható az alkotmányban. Az alkotmányos intézményeket és múködésüket, illetve az állampolgárok demokratikus szabadságjogait, valamint a rend és a biztonság fenntartását a szövetségi hadsereg biztosítja. ${ }^{20} \mathrm{~A}$ krízishelyzetre vonatkozó részletes szabályozást a szövetségi had-

16 Az első modern európai alkotmány, az 1791-ben született lengyel alkotmány is a következő, különleges szabályokat igénylő helyzeteket ismerte: nemzetközi jogi kivételes helyzetek („különösen egy szomszédsági háborúban”), belső zavargások, „amelyek az országot [...] forradalommal fenyegetik”) az „általános éhínség nyilvánvaló veszélye”, a „szülőhaza elárvulása” a király betegsége vagy halála okán (Wißmann, 2015, 14. o.).

17 B-VG 9a. cikk (1) bekezdés.

18 B-VG 9a. cikk (3) bekezdés.

19 B-VG 80. cikk.

20 B-VG 79. cikk (2) bekezdés. 
seregről ${ }^{21}$ szóló törvény mellett a biztonsági rendőrségről, ${ }^{22}$ illetve a rendőrségi államvédelemről szóló törvény ${ }^{23}$ tartalmazza.

A harmadik kategóriát a "katasztrófa” elnevezés alá tartozó események képezik. Idesorolandók például a természeti katasztrófák, túzvész, illetve egyéb, az átlagosnál nagyobb méreteket öltő szerencsétlenségek. Ezen helyzetek kezelése túlnyomórészt a szövetségi tartományok hatáskörébe tartozik. Konkrét szabályanyaguk ugyan eltérhet egymástól, közös elem azonban, hogy a kialakult állapot megfékezéséhez bevonják a tủzoltókat, rendôrségi erőket, és ha szükséges, az állampolgárokat is. A szövetségi szint hatáskörébe tartozik a közlekedés és az egészségüggyel kapcsolatos súlyos helyzetek kezelése, valamint a járványok leküzdése is.

A negyedik csoport azon gazdasági, szociális és humanitárius természetú válsághelyzeteket öleli fel, amelyekben közös, hogy logisztikai jellegúek, és általuk az olyan alapvető javak, mint az élelmiszer-, víz- és energiaellátás veszélyeztetettek. E körben megemlítendő, hogy háborús helyzet kialakulása esetén - csakúgy, mint azokban a szituációkban, amikor a lakosság szükségleteit kell biztosítani - ezen intézkedéseket állami szinten kell megtenni. ${ }^{24}$

Noha a konkrét, a különleges jogrendet megalapozó esetek meghatározása az alkotmányban nem történik meg, és arra vonatkozóan is csak kivételesen találunk utalást, hogy az ezek fennálltában való döntés kinek az illetékességi körébe tartozik, ez - elsősorban az eljárásba beépített előzetes kontroll okán, a szakmai kritikák ellenére - sem jelent a gyakorlatban utóbb jogbiztonságot vagy alkotmányossági kritériumokat veszélyeztető elemet.

\section{Az alapjogok korlátozására vonatkozó szabályok különleges jogrend idején}

Az osztrák alkotmányjog két nagy csoportba sorolja azokat a vészhelyzeti elő́rásokat, amelyek a témakörben relevánsak, annak függvényében, hogy a vészhelyzeti előirások kompetenciabővitő jellegúek-e, vagy sem, illetve mennyiben korlátozhatják az alkotmányban garantált alapjogokat.

Az osztrák alkotmány két olyan rendelkezést ${ }^{25}$ tartalmaz, amely anélkül ad lehetóséget az állam és az állami szervek cselekvőképességének fenntartására, hogy ezzel együtt megadná a jogot azok speciális, bővített kompetenciakeretekkel történő kezelésére is.

Az 5. cikk rögzíti, hogy valamennyi legfelsőbb szintû szövetségi szervezet székhelye az osztrák szövetségi fơvaáros. Rendkívüli körülmények esetén azonban az osztrák szö-

\footnotetext{
21 Törvény a szövetségi hadseregről 2001 (Wehrgesetz 2001).

22 Törvény a biztonsági rendőrségről (Sicherheitspolizeigesetz).

23 A rendőrségi államvédelemről szóló törvény (Polizeiliches Staatsschutzgesetz).

24 B-VG 10. cikk (1) bekezdés 15. pont.

25 B-VG 5. és 79. cikk.
} 
vetségi elnök a szövetségi kormány kérésére - saját mérlegelést követően - ezt a szövetség területén más helyszínre áthelyezi. Nem kerül meghatározásra azonban a rendkívüli körülmény fogalma. Az alkotmány nevesítetten egy ilyen esetcsoportot jelöl meg, ${ }^{26}$ amely esetek közös jellemzője, hogy háborús vagy háború utáni állapotok. A szakirodalomban ${ }^{27}$ azonban erős az a megközelítés, hogy a rendkívüli körülmény tartalmilag nem szúkíthetô le erre a 15. pontra. Idesorolható a belső vagy jelentős nemzetközi politikai válság, széles körú társadalmi nyugtalanság, súlyos természeti katasztrófa csakúgy, mintha a helyváltoztatást a fơváros területi védelme kívánná meg.

A másik az alkotmány 79. cikke, amely a szövetségi hadsereg békeidejü tevékenységéről tartalmaz rendelkezéseket. ${ }^{28} \mathrm{~A}$ haza katonai védelmén túl a szervezet szerepet vállal a belső rend és biztonság, az alkotmányos intézmények és az állampolgárok demokratikus szabadságának védelmében, de közremúködik rendkívüli méretú elemi csapások és szerencsétlenségek esetén a segítségnyújtásban is. Erre azonban csak a törvényes polgári hatalmon keresztül kerülhet sor. Önálló katonai beavatkozás e tevékenységek keretében csak kivételesen és akkor lehetséges, ha az arra felhatalmazott szervet valamely magasabb hatalom képtelenné teszi a katonai beavatkozás foganatosítására, a további késedelem pedig például helyrehozhatatlan kárt okozna a társadalom tagjainak. ${ }^{29}$ Ilyen lehet a tényleges támadás visszaverése vagy a szövetségi hadsereg valamely egysége elleni erőszakos ellenállás felszámolása, a szabotázzsal vagy a terrorista cselekménnyel szembeni fellépés. A „valamely magasabb hatalom" fogalma nincs megadva, de vis maiornak minősülhet a szakirodalom szerint például, ha egy földrengés vagy lavina miatt az út- és vasúthálózat használhatatlanná válik, a telekommunikáció megsemmisül, s így a szövetségi hadsereg adott egységével az összeköttetés nem hozható létre. Hasonlóképpen az olyan belső felkelés is, amely megbénítja a törvényes polgári hatalom gyakorlását. A szövetségi hadsereg fennmaradó ereje ilyen esetekben sem maradhat tétlen, ha fellépésük egyéb alkotmányos feltételei fennállnak. Ekkor a döntés az adott katonai parancsnok kezében van. Amennyiben a törvényes polgári hatalom visszaszerzi „cselekvőképességét”, a fegyveres erők e jogosultsága megszúnik.

A kompetenciahatárokat kiterjesztő sürgősségi törvényi rendelkezések a szövetségi és tartományi alkotmányok, illetve egyéb releváns törvények azon rendelkezéseit ölelik fel, amelyek egy intézmény, illetve személy hatáskörét olyan területekre is kiterjesztik, amelyeket az általános szabályok más szervezethez vagy személyhez rendelnek. Ebbe a csoportba tartozik a szövetségi elnöknek, ${ }^{30}$ az adott tartomány kormányának, ${ }^{31}$ illetve kormányzójának ${ }^{32}$ sürgősségi rendeletalkotási joga csakúgy, mint a szövetségi kormány gazdaságirányítással

26 B-VG 10. cikk (1) bekezdés 15. pont.

27 Így például Wiesert hivatkozza Reindl-Krauskopf, 2016, 139. o.

28 B-VG 79. cikk (2) bekezdés.

29 B-VG 79. cikk (5) bekezdés.

30 B-VG 18. cikk (3)-(5) bekezdés.

31 B-VG 97. cikk (3)-(4) bekezdés.

32 B-VG 102. cikk (5) bekezdés. 
és az ellátásbiztonsággal kapcsolatos törvényhozási hatásköre. Noha több esetkör is ismert, Ausztriában nincs egységes alkotmányos szabályozás a sürgősségi törvényi felhatalmazások tekintetében, szemben néhány más európai országgal (például Svájc, Franciaország, Svédország).

Így például a tartományi kormányzó sürgősségi rendelet kiadására vonatkozó joga a törvényi feltételek mellett is csak a közvetlen szövetségi közigazgatás alá eső ügyekre korlátozódik - azaz nem teljes körrel járhat el a szövetségi közigazgatás legfelsőbb szervei helyett. Az alkotmány értelmében erre akkor kerülhet sor, ha az adott tartományban egy nyilvánvaló, a közösséget érintő, helyrehozhatatlan kár elhárításához lenne szükség az intézkedések azonnali megtételére, az erre hatáskörrel és illetékességgel rendelkező szövetségi közigazgatási legfelsőbb szervek azonban vis maior okán erre nem képesek („akadályozottak”).33 Ebben az esetben az intézkedések meghozatala nem lehetősége, hanem az alkotmány értelmében kötelessége a tartományfőnöknek. ${ }^{34} \mathrm{~A}$ szabályozás hátterében annak szándéka állt, hogy megelőzhető legyen a tartomány leállása abban az esetben, ha az ideiglenesen (például lavina, földomlás, rendkívüli időjárási viszonyok okán) elzáródik a szövetségi székhelyen található központi szervektől. ${ }^{35}$

Vészhelyzeti kompetencia illeti meg a tartományi kormányt is, amennyiben a vis maior helyzet fennállta okán a nyilvánvaló, a közösséget érintő helyrehozhatatlan kár elhárításához szükség lenne azonnali intézkedések foganatosítására, azonban a határozathozatalra jogosult tartományi gyưlés nem képes időben összeülni, vagy tevékenységében vis maior miatt akadályozott. Az alkotmány szerint a tartományi kormány - az arányos választás alapelvének megfelelően kinevezett tartományi gyúlési bizottság egyetértésével - ezt átmeneti törvénymódosító rendelettel megteheti ${ }^{36}$ Feltétele, hogy a tartományi alaptörvényt nem módosíthatja, de ezen túl nem vonhatja magával például a tartomány vagy a szövetség tartós anyagi megterhelését, nem keletkeztethet az állampolgárokra anyagi kötelezettséget, de nem jelentheti az állami vagyon elidegenítését sem. ${ }^{37} \mathrm{~A}$ sürgősségi rendeleteket a tartományi kormány haladéktalanul a szövetségi kormány tudomására kell hozza. Ezzel annak lehetősége is adott, hogy a szövetségi kormány azt alkotmányossági kontroll céljából közvetlenül az alkotmánybíróság elé terjessze. ${ }^{38}$ Bár a szabályozás struktúrájában és fóbb tételeiben visszatükrözi a szövetségi vészhelyzeti rendeletalkotási modellt, azonban itt - szemben a szövetségi szinttel - nincs szükség a bizottság „kifejezett hozzájárulására”.

Speciális szabályok kapcsolódnak a közvetlen gazdasági ellenőrzés területén illetékes szövetségi miniszterhez is. ${ }^{39} \mathrm{Az}$ időleges, kvázi vészhelyzeti kompetencia lényegileg egy,

33 B-VG 102. cikk (5) bekezdés.

34 A tartományfőnök a tartományi kormányzat vezetője, akit a tartományi parlament választ.

35 Peter Bußjägert és a Rill-Schäffer-kommentárt hivatkozza: Augustin, 2016, 67. o.

36 B-VG 97. cikk (3) bekezdés.

37 B-VG 97. cikk (4) bekezdés.

38 B-VG 139. cikk (1) bekezdés 6. pont.

39 B-VG 55. cikk (5) bekezdés. 
a szabad piacgazdaságba történő közvetlen beavatkozási lehetőséget biztosít az állam számára, ezért alkalmazhatóságára szigorú arányossági teszt mentén kerülhet sor. Az alkotmány értelmében az illetékes szövetségi miniszter a zavartalan termelést vagy a lakosság és más felhasználók fontos gazdasági és fogyasztási cikkekkel való ellátását célzó irányítási intézkedéseit tartalmazó rendeleteihez a Nemzeti Tanács főbizottságának jóváhagyására van szükség. (Sőt, a főbizottság határozatához tagjai legalább felének jelen kell lennie, és a leadott szavazatok kétharmadának támogató jellegúnek kell lennie.) Az érintett területek tipikusan az energiaszabályozás, olajkészletek, ellátásbiztonság, élelmiszer-gazdálkodás és árszabályozás. A szakirodalom értelmében ${ }^{40}$ fontos feltétel, hogy egy már bekövetkezett vagy legalábbis küszöbön álló azonnali ellátási zavar fenyegessen - kivéve, ha az piackompatibilis intézkedésekkel is kezelhetô.

Különleges jogrendi jogalkotási joggal (Notverordnungsrecht) - az alkotmány értelmében - a szövetségi elnök rendelkezik, ${ }^{41}$ amellyel háború, természeti katasztrófa és más vészhelyzetek esetében a kormány javaslatára élhet. Az alkotmányos szabályozás elméleti tételei itt is azonosak: amennyiben köztudomású, a nyilvánosság (közösség) számára jóvátehetetlen kár elhárítása érdekében a Nemzeti Tanács határozathozatalát igénylő intézkedések azonnali meghozatala olyan időpontban válik szükségessé, amikor a Nemzeti Tanács nem ülésezik, nem tud időben összeülni vagy tevékenységében felsőbb hatalom által akadályoztatott, a szövetségi elnök a szövetségi kormány javaslatára, saját vagy annak felelössége mellett megteheti a szükséges intézkedéseket ideiglenes, törvénymódosító rendeletek útján. Ezek érvényességéhez azonban szükség van - többek között - a szövetségi kormány ellenjegyzésére is. A szövetségi elnök vészhelyzeti kompetenciáinak több irányból is szigorú keretei és garanciális kontrollelemei vannak. Így például az alkotmány kizárja annak lehetôségét, ${ }^{42}$ hogy e jogi aktusok a szövetségi alkotmánytörvény rendelkezéseit módosítsák, mint ahogy nem keletkeztethetnek anyagi terhet sem a szövetség, sem a tartományok, sem az állampolgárok számára. Egyebekben az alkotmány azt is rögzíti, hogy a szövetségi kormány sürgősséggel hozott valamennyi rendeletét köteles haladéktalanul a Nemzeti Tanács elé terjeszteni, amelyet az előterjesztést követő 8 nap valamelyikére a szövetségi elnök hív össze, amennyiben a Tanács az adott időpontban nem ülésezik. ${ }^{43}$ Amennyiben igen, úgy annak elnökére hárul ez a feladat. Az előterjesztést követő négy héten belül a Tanács a rendelet helyére vagy egy megfelelő szövetségi törvényt hoz, vagy határozat útján követeli, hogy a szövetségi kormány azonnal helyezze hatályon kívül a rendeletet. Az utóbbi esetben a kormány köteles azonnal eleget tenni ennek a követelésnek. A Nemzeti Tanács időbeni határozathozatala céljából az elnök az elooterjesztést legkésőbb a négyhetes határidő utolsó előtti napján köteles szavazásra bocsátani; a részletes rendelkezéseket az ügyrend tartalmazza. Ameny- 
nyiben a rendeletet az előzőek alapján a szövetségi kormány hatályon kívül helyezi, ezzel egyidejúleg ismét hatályba lépnek azok a törvények, illetve szabályok, amelyeket a rendelet helyezett hatályon kívül.

Összességében rögzíthető, hogy Szabó István megállapításai a hatályos szabályozás kapcsán is irányadók: a szövetségi elnök „a szúkebb körbe tartozó kivételes hatalmat kapta meg, az alkotmány ugyanis pontosan rögzítette a kivételes hatalom körében alkalmazható eszközöket. Igazából nem is kell többes számban beszélnünk, mert egy eszköz volt, a törvényerővel bíró rendelet. Kivételes helyzetben eljárhatott a Nemzeti Tanács hatáskörében, de ezen túli rendkívüli hatalomgyakorlásra nem kapott felhatalmazást." ${ }^{{ }^{4} 4} \mathrm{Az}$ osztrák alkotmány ezen esetkör kapcsán sem teszi lehetôvé a tágabb kivételes hatalom lehetőségét. Ez esetben nemcsak olyan döntést hozhat egy államhatalmi szerv, amelyre nincs illetékessége, hanem olyan tartalmút is, amelyre egyébként az arra illetékes szerv sem lenne jogosult.

Az osztrák alkotmány szúk körben tartalmaz konkrét különleges jogrendi rendelkezéseket. Az alapjogok korlátozásával járó döntések alapját és kereteit speciális jogszabályokban - többek között a járvány(ügyi), ${ }^{45}$ a szövetségi biztonsági rendőrségről ${ }^{46}$ vagy a rendőrségi államvédelemról szólós7 törvényben - találhatjuk meg, amelyek meghatározott feltételek mellett komoly alapjogi korlátozásokat is megengednek a kormány, illetve az illetékes hatóságok számára. Így a biztonsági rendőrségről szóló hivatkozott törvény a szervezet hatáskörébe utalja számos olyan jogintézmény (például a kitiltás) alkalmazásának lehetőségét, amelyek - bár időben és térben korlátozottak - részben helyettesíthetik a kijárási tilalom elrendelhetőségét; egészségügyi indokoltság esetén ezt a Járványügyi tv. is lehetővé teszi. A rendészeti válságkezeléssel kapcsolatos szabályozás lehetséges területei közül például a közúti közlekedésről szóló rendelet ${ }^{48}$ felhatalmazást ad az illetékes hatóság számára, hogy forgalmi tilalmakat vagy korlátozásokat adjon ki, többek között a már bekövetkezett vagy közelgő természeti katasztrófák (például hegyomlás, lavina vagy annak veszélye) esetén. De hasonló tartalommal foganatosíthatnak intézkedéseket például a közúti felügyeletért felelős szervezetek rendkívüli - így az olyan alapvető javakkal, mint az élelmiszerrel, vízzel és energiával való ellátás, illetve a környezet veszélyeztetésével járó - helyzetek megelőzése, illetve kezelése esetén is. A forgalomkorlátozás, illetve -tiltás a gyakorlatban jól múködő, hatékony válságkezelési eszköz, légi, hajó- vagy vasúti forgalom felé történő kiterjesztése nem indokolt. ${ }^{49}$

Bár az egyes jogforrások nevesítik az alapjog-korlátozást is biztosító rendelkezések alkalmazására illetékes intézmények és személyek körét, két szervezet önálló kiemelése katasztrófa-, illetve krízishelyzetek kapcsán nem mellőzhető. Az Állami Válság- és Ka-

44 Szabó, 2010, 188. o.

45 Járvány(ügyi) törvény (Epidemiegesetz 1950) (a továbbiakban: Járványügyi tv.).

46 A szövetségi biztonsági rendőrségről szóló törvény (Sicherheitspolizeigesetz).

47 A rendőrségi államvédelemról szóló törvény (Polizeiliches Staatsschutzgesetz).

48 A közúti közlekedésről szóló rendelet (Straßenverkehrsordnung 1960).

49 Reindl-Krauskopf et al., 2016, 169. o. 
tasztrófavédelmi Menedzsment ${ }^{50}$ (SKKM) és a Nemzeti Biztonsági Tanács ${ }^{51}$ (NSR) szerepe meghatározó például zavargások, terrortámadás, katasztrófahelyzet, egészségügyi válsághelyzet vagy kibertámadás esetén is, függetlenül attól, hogy ezeket az alkotmány csak részben nevesíti, s erre vonatkozóan speciális szabályokat teljes körben nem tartalmaz.

2003 májusa óta a Szövetségi Belügyminisztérium felel az állami válság- és katasztrófavédelem kezeléséért, valamint a nemzetközi katasztrófaelhárítás koordinálásáért. Az SKKM-et 2004-ben szervezték újjá, ${ }^{52}$ létrehozva egy új koordinációs bizottságot, amelyet a közbiztonsági fóigazgató vezet. 2006-tól az Operatív és Koordinációs Központ53 (EKC) részét képezi a Szövetségi Figyelmeztetô Központ ${ }^{54}$ (BWZ), amely információs és állandó nemzeti kapcsolattartó pontként szolgál, közvetítve a tartományok, a szomszédos országok, az Európai Unió és az összes nemzetközi szervezet felé. A megelőzés előmozdítása mellett az SKKM lehetôvé teszi a hatékony katasztrófaelhárítást az összes felelős szövetségi ügynökség együttmúködésével, a tartományok katasztrófavédő hatóságai, a segély- és mentőszervezetek bevonásával válságok vagy katasztrófák esetén. ${ }^{55}$ Attól függően, hogy a fenyegetô veszély milyen horderejü és mekkora területet érint, a feladatok ellátásáért a járási főnökség, a polgármester, a tartományi kormány vagy a kifejezetten ilyen segítségnyújtásra létrehozott úgynevezett segélyszervezetek felelnek, amelyek az adott feladat ellátásáért felelős szerv alatt múködnek. ${ }^{56}$ Ilyenek például a tưzoltóság, a rendőrség vagy az osztrák fegyveres erők segítő csapatai. E körben megemlítendő, hogy a régiókon átnyúló fenyegetések szövetségi szinten kezelendők, ezzel szemben a válsághelyzet és katasztrófakezelés a helyi struktúrákban elsődlegesen az önsegély elvén alapul, azaz helyi szinten szükséges intézkedéseket foganatosítani. ${ }^{57} \mathrm{Az}$ átfogó biztonsági és katasztrófaelhárítási szolgáltatásokat segíti az önkéntes szervezetek közremúködése is a segítségnyújtási rendszerben. Katonai erők bevonásának lehetősége szövetségi szinten adott, a hatóságok és a polgári védelmi szervek révén pedig a lakosság is bekapcsolódik a reagálásba. Válsághelyzetben az illetékes szervek speciális felhatalmazással bírnak, ${ }^{58}$ így joguk (és egyben kötelezettségük is) a zavargás vagy felkelés jogi keretek közötti elnyomása, amelyhez egyéb jogszabályok (például a fegyverhasz-

50 Staatliches Krisen- und Katastrophenschutzmanagement (SKKM). Elérhető: www.bmi.gv.at/204/skkm/start.aspx (Letöltve: 2020. február 15.).

51 Nationaler Sicherheitsrat(NSR) Elérhető:www.bundeskanzleramt.gv.at/themen/sicherheitspolitik/nationalersicherheitsrat.html (Letöltve: 2020. február 15.).

52 Lásd a Belügyminisztérium feljegyzését: www.bmi.gv.at/204/SKKM/files/001_Ministerratsbeschluss.pdf (Letöltve: 2020. február 15.).

53 Einsatz- und Koordinationscenter (EKC). Elérhető: www.bmi.gv.at/103/Sektion_II/EKC/start.aspx (Letöltve: 2020. február 15.).

54 Bundeswarnzentrale (BWZ). Elérhető: www.bmi.gv.at/204/skkm/Bundeswarnzentrale.aspx (Letöltve: 2020. fenruár 15.).

55 Bundesministerium für Inneres, 2013.

56 Lásd erről: Jachs, 2011.

57 Lásd erre például Baden-Württemberg tartomány saját katasztrófavédelmi törvényét.

58 Reindl-Krauskopf et al., 2016, 177. o. 
nálati törvény ${ }^{59}$ további speciális felhatalmazást adnak, természetesen az arányosság követelményének szigorú figyelembevétele mellett.

A válságkezeléssel összefüggésben a másik - bár más körben pozicionált - kompetens szervezet a Nemzeti Biztonsági Tanács (NSR), amelyet az USA-t 2001. szeptember 11-én ért terrortámadások hatására állítottak fel. Az NSR két fő feladatköre a szövetségi kormány és egyes miniszterek számára történő tanácsadás, valamint a megfelelő intézkedések előkészítése a kül-, biztonság- és védelempolitika minden alapvető kérdésében, beleértve a válsághelyzeteket generáló szituációkat is. Tagjai részben meghatározott kormányzati pozícióban lévő személyek, részben a politikai pártok képviselői, elnöke a mindenkori osztrák kancellár.

A támadásokkal szembeni hatékony védelem szükségessé tette, hogy egyes válsághelyzetet generáló szituációk megelőzése kapcsán önálló szervezeti egységeket hozzanak létre. Ilyen a kibertámadásokkal szembeni fellépést koordináló Kiberbiztonsági Irányítócsoport, illetve az Alkotmányvédelmi és Terrorizmusellenes Szövetségi Hivata ${ }^{60}$ mint a rendőrség állami védelmet szolgáló hatósági egysége.

Az SKKM 2020-as stratégiája külön nevesíti a technikai innováción keresztül történő hatékonyságnövelés fontosságát. ${ }^{61} \mathrm{~A}$ stratégia a kibertér nem megfelelő müködésétől az állami és nem állami szereplők számítógépes rendszereinek közvetlen támadásáig minden aktivitást átfog, ahol a kibertér szolgál a különféle akciók terepeként, s amelyek nem állnak meg a nemzeti határokon. A Miniszterek Tanácsa 2012-ben hívta életre a Szövetségi Kancellária vezetésével a Kiberbiztonsági Irányítócsoportot, ${ }^{62}$ amelynek célja - többek között - a kiberbiztonsági intézkedések koordinálása, jelentéskészítés, tanácsadás és a Kiberbiztonság Megteremtését Célzó Osztrák Stratégia ${ }^{63}$ (ÖSCS) végrehajtásának figyelemmel kísérése. Az irányítócsoport állandó (például NSR-összekötő tisztviselők, kiberbiztonsági szakértők) és ideiglenes (más minisztériumok, szövetségi államok) tagokból, az állam képviselőiből és a kritikus infrastruktúrák üzemeltetőiből áll. A felelősség azonban megoszlik (az ország belső biztonságát veszélyeztető/fenyegetô támadás esetén a Szövetségi Belügyminisztérium, külső biztonság szempontjából releváns attaknál a Szövetségi Védelmi és Sportminisztérium kerül vezetố szerepbe; utóbbi esetén a katonai nemzetvédelem adja a tevékenység keretét).

59 Fegyverhasználati törvény (Waffengebrauchsgesetz).

60 Bundesamt für Verfassungsschutz und Terrorismusbekämpfung (BVT). Elérhető: www.bvt.gv.at/ (Letöltve: 2020. február 15.).

61 Lásd itt a 6. oldalt: www.kiras.at/fileadmin/_migrated/content_uploads/SKKM_Strategie_2020__Final_ Juli_09.pdf (Letöltve: 2020 . február 1.).

62 Cyber Sicherheit Steuerungsgruppe (További információ elérhető a Bundeskanzleramt [Strategie für Cyber-Sicherheit] honlapjáról: www.bundeskanzleramt.gv.at/themen/sicherheitspolitik/cyber-sicherheit.html [Letöltve: 2020. február 15.].

63 Elérhető: www.bundeskanzleramt.gv.at/dam/jcr:d785192e-8c9d-4c67-8af9-f292371de8c9/\%C3\%96sterreichis che\%20Strategie\%2of\%C3\%BCr\%20Cyber\%20Sicherheit.pdf(Letöltve: 2020. február 1.). 
A Digitális Ausztria információs és kommunikációs technológiabiztonság64 általános elvei korlátozás nélkül alkalmazandók a kiberbiztonság területére is; ezek a titoktartás, integritás, felelősség, hitelesség, elérhetőség, a privát szféra csakúgy, mint az adatok védelme. Ennek megteremtése, illetve biztosítása szintén a Kiberbiztonsági Irányítócsoport feladata.

A különleges jogrenddel és a különböző válsághelyzetek kezelésével kapcsolatban mindig is érzékenyen reagált az osztrák szakmai közeg, amit az újkori népvándorlások első hulláma során tapasztaltak csak tovább fokoztak. A kritika alá vetett rendelkezésekkel összefüggésben 2016-ra több javaslat ${ }^{65}$ is megfogalmazódott.

Az alkotmány értelmében meghatározott feltételek mellett kerülhet sor arra, hogy az alkotmánybíróság egy jogszabály jogellenességét megállapítsa. ${ }^{66}$ Így például szükséges egy olyan személy kérelme, aki azt állítja: a jogellenesség okán jogai közvetlen sérelmet szenvednek, ha az adott rendelet bírósági döntés vagy határozat elfogadása nélkül lép (ôt érintően) hatályba. ${ }^{67} \mathrm{Az}$ osztrák válságkabinet rendeleteinek alkotmánybírósági kontrollja kiemelt elvárás a szakirodalom tárgyalásában. Ezzel összefüggésben rögzítik például, hogy fontos lenne az alkotmánybíróság B-VG 139. cikkelye szerinti felülvizsgálati lehetőség biztosítása akkor is, ha annak időpontjában a vitatott rendelet (jogi norma) már nincs hatályban (lejárt). Ekkor ugyanis hiányzik az idézett törvényi feltétel: már nem áll fenn a kérelmező jogi szférájának közvetlen sérelme. Ilyen esetben lehetővé kellene tenni a norma jogellenességének „lejárat” utáni megállapíthatóságát is.

Ezzel összefüggésben rögzítik a rendeleti jogalkotás rendszeres alkotmánybírósági felülvizsgálatának hiányát azok rövid érvényességi időtartama miatt. Így fogalmazódott meg a gyorsított eljárás alkalmazhatóságának igénye.

Hasonló nehézséget jelent az alkotmányellenes rendelettel összefüggésben anyagi kártérítés fizetése. A jelenleg hatályos, a helyi hatóságok (önkormányzatok), az egyéb hatóságok és a közjogi intézmények felelősségéről szóló törvény ${ }^{68}$ több feltétel együttes fennállásához köti ${ }^{69}$ a kártérítés kifizetését, ezzel jelentősen leszúkítve annak gyakorlati alkalmazhatóságát. Ezért megfontolásra kínálta a szakirodalom a kompenzációs modell alkalmazását; így az anyagi kártérítés a rendelet jogellenességének utólagos megállapítása esetén külön jogi aktus nélkül is megilletné a sérelmet szenvedett felet.

64 'Sicherheit in der Informations- und Kommunikationstechnik (IKT)' E-Government in Österreich in Digitales Österreich. Elérhető: www.digitales.oesterreich.gv.at/sicherheit-in-der-ikt (Letöltve: 2020. február 1.).

65 Reindl-Krauskopf et al., 2016, 238-239. o.

66 B-VG 139. cikk.

67 B-VG 139. cikk (1) bekezdés.

68 Amtshaftungsgesetz (AHG).

69 Így például nem áll(hat) fenn kártérítési igény abban az esetben, ha a sérelmet szenvedett fél a kárt jogorvoslattal, a közigazgatási bírósághoz benyújtott panasszal vagy a közigazgatási törvényszéknél indítványozott felülvizsgálattal elháríthatta volna [AHG 2. \$ (2) bekezdés]. A kártérítési igény az alkotmánybíróság, a legfelsőbb bíróság vagy a közigazgatási bíróság határozatából automatikusan nem vezethető le [AHG 2. \$ (3) bekezdés). 
A gyakorlat és alkalmazhatóság oldaláról az osztrák jogrend által biztosítottak még azon sürgősségi jogi normák is, amelyek lehetôvé teszik az állami szervek kompetenciakeretének bővítését, megoldásaik okán azonban nem igazán veszik figyelembe a szükséghelyzetek által megkövetelt gyorsaságot, könnyú alkalmazhatóságot, valamint a felhatalmazás szükségességét. Igaz ez az alkotmányban rögzített különleges jogrendi rendelkezések, a szövetségi elnök sürgősségi rendeletalkotási jogára is. Bár a terrorizmus „európaizálódása”, illetve felerősödése - különösen 2001. szeptember 11. - után számos szervezeti változtatást foganatosított az állam, különösen a migrációs hullámmal kapcsolatos éles helyzet mutatott rá arra, hogy még további lépésekre van szükség. A menekültválsággal kapcsolatos negatív tapasztalatok tipikusan azzal összefüggésben merültek fel, hogy az illetékes hatóságok, illetve tisztviselók nem tudtak megfelelő gyorsasággal döntést hozni, illetve azok végrehajtása is túl nehézkes volt. Azaz egyértelmú eljárási és döntéshozatali struktúrákra s ezen keresztül egy új válságkezelési rendszerre volt szükség. ${ }^{70} \mathrm{~A}$ kritikák hatására bekövetkező aktivitások keretében létrehozott hattagú Biztonsági Kabinet feladata ${ }^{71}$ a katasztrófa- és válsághelyzeti koordináció. Tagjai a szövetségi kancellár, az alkancellár, valamint a védelmi, a külügy-, a pénzügy- és a belügyminiszter. Válsághelyzetben a szövetségi kormány kérésére 24 órán belül összeül, s üléseit ennek függvényében tartja, garantálva a gyors döntéshozatalt és a „hatékony biztonságirányítást”. A döntések megalapozottságát biztosítja, hogy azok meghozatala egyhangúlag történik - azaz a kancellárnak sincs utasításadási joga a testület felé. További változás, hogy a fegyveres erők feladatköre is bővült. Feladatuk a módosító rendelkezések hatására kiterjedt a kritikus infrastruktúrák védelmére, s jogot kaptak a határok átlépésére is, ha az a repülőgépek üldözése érdekében szükséges. Ennek foganatosításához számos további diplomáciai, jogi lépés szükséges (elsőként Svájc neve merült fel).

Alkotmányos módosítások a terrorizmussal szembeni hatékonyabb fellépés érdekében egyébként is indokoltnak tûntek, ${ }^{72}$ figyelemmel a kritikák hatására született azon tervekre, amelyek közt például a hatékonyabb terrormegelőzés érdekében a közterületek fokozott megfigyelésének kérdése szerepelt. Mindazonáltal a többségében 2016-ban realizálódott változásokat is érte már kritika. ${ }^{73}$ Egyrészt a tekintetben, hogy bár a Biztonsági Kabinet a múködési mechanizmusa okán megfelel a gyorsaság követelményének, valódi hatékonysága a szakirodalom szerint a parlamenthez való kapcsolata minőségétől függ. A kritikusok szerint valódi felhatalmazás és hatáskör nélkül nem tud eredményesen múködni a bizottság. Véleményük szerint ehhez akár a hatalomszétválasztás elvét is érintő széles körű intézkedési kompetenciákra van szükség. Az egyéb veszélyhelyzetekhez képest kevéssé súlyosnak értékelt mene-

70 Lásd a Wiener Zeitung 2016-os cikkét: www.wienerzeitung.at/nachrichten/politik/oesterreich/847111_ Bundesheer-erhaelt-mehr-Befugnisse.html (Letöltve: 2020 . november 11.).

71 Lásd a Belügyminisztérium 2017-es anyagának 51. oldalát: Mehr Freiheit. Mehr Sicherheit. Die Sicherheitsdoktrin des BMI für Österreich 2017-2020. Elérhető: www.bmi.gv.at/bmi_documents/1977.pdf (Letöltve: 2020. április 6.).

72 Seidl, 2016.

73 Augustin, 2016, 100-101. o. 
kültügyi válság kezelésének akadályozottsága azt is megmutatta, hogy az osztrák alkotmány különleges jogrendi szabályozásának felülvizsgálata és módosítása elkerülhetetlen lenne.

Áttekintve azokat az osztrák alkotmánybíróság, legfelsőbb bíróság, közigazgatási legfelsőbb bíróság által hozott döntéseket, ${ }^{74}$ amelyek - a pandémia kezelésétől eltekintve alapjog-korlátozásokkal összhangban születtek, megállapítható, hogy ezek döntő többsége különböző állampolgárságú (például szír, afgán, algériai, iráni, török) menekült személyeket érintő intézkedésekkel, menedékkérelmük elutasításával, illetve a belépő államba (például Olaszország) történő kitoloncolásuk elrendelésével vagy foganatosításával összefüggésben indult eljárásokban születtek. Ausztria nevével egyéb, alapjogsérelemmel kapcsolatos ügyben ritkán találkozni az Emberi Jogok Európai Bírósága előtt. Ilyen volt például a Schalk és Kopf kontra Ausztria ügyben 2010-ben született döntés. ${ }^{75}$

\section{A különleges jogrend kihirdetésének gyakorlati esetei}

Noha Ausztria újkori történetének legnagyobb krízishelyzete a Covid-19, amely a járványügyi rendelkezések eddig nem tapasztalt széles körú alkalmazását hozta, veszélyhelyzet idején alkalmazandó különleges jogrendi alkotmányos rendelkezések igénybevételére - figyelemmel a parlament mindkét kamarájának folyamatos ülésezésére - nem került sor. Ehelyett a Nemzeti Tanács átfogó jogszabályi csomagot ${ }^{76}$ készített 2020 márciusában, amely a Járványügyi tv. mellett a Covid-19 terjedésének lassítását célzó különféle intézkedések jogalkotási alapjául szolgált.

A számtalan korlátozó rendelkezés alkalmazásának keretét a különböző törvények célzott módosítása tette lehetôvé. E körből is kiemelkedik a Járványügyi tv., amelyet „egyszerư" jogtechnikai megoldással tettek jelen helyzetre is alkalmazhatóvá. A törvény nevesíti azokat a betegségeket (például lepra), amelyek esetén a jogszabály igen jelentős korlátozó intézkedései alkalmazhatók. ${ }^{77}$ Ez már tartalmazta a közel-keleti légzőszervi szindrómát (MERS-CoV), amely 2012-ben az Arab-félszigetről kiinduló, szintén koronavírus által okozott betegség. Ez került rövid kiegészítésre az új típusú koronavírus szerepeltetésével (neues Corona-Virus). A törvény - már kimondottan a Covid-19 vonatkozásában - többek között kimondja, hogy az elkülönítési intézkedéssel (karantén) érintett (beteg vagy potenciálisan fer-

74 European Union Agency for Fundamental Rights (FRA) Casa Law Darabase. Elérhető: https://fra.europa.eu/en/ case-law-database?field_fra_country\%5B0\%5D=995\&search_api_views_fulltext=\&sort_by=field_info_ decision_date\&sort_order=DESC\&page=1 (Letöltve: 2020 . április 6.).

75 Ilyen volt például a Schalk és Kopfkontra Ausztria ügyben 2010-ben született döntés. Michael Schalk és Johan Franz Kopf kérelmezők még 2004. augusztus 5-én azért fordultak a nemzetközi bírósághoz, mert hazájukban jogsérelem - és megkülönböztetés - érte őket, amennyiben azonos nemú párként az állam megtagadta tőlük a házasságkötés lehetőségét. Hiába éltek együtt, kapcsolatukat az állam nem ismerte el. [ECtHR/Application no. 30141/04/Judgement (Schalk and Kopfv. Austria)].

76 Lásd erről: Parlamentskorrespondenz Nr. 263 vom 15. Marz 2020.

77 Járványügyi tv. 1. \$. 
tőzött) személyek kapcsán a kerületi közigazgatási hatóság kap felhatalmazást arra, hogy a település polgármestere részére kiadja az intézkedés alá vont személy nevét és elérhetőségi adatait további ellátás, intézkedés stb. céljából. ${ }^{78}$

Az osztrák kormány jogszabályalkotói tevékenységének szakmai hátterét az úgynevezett Korona(vírus)-bizottság (Corona-Kommission) adja. A bizonyítékokon alapuló folyamatos kockázatértékelést végző tanácsadó testület a 9 tartomány képviselőin túl a szövetségi állam tudós szakértőiből, illetve a releváns szövetségi szintű hatóságok képviselőiből áll. A bizottság mind szövetségi, mind tartományi szinten rendelkezik minden szükséges információval, s összetételéből adódóan mind a tudományos, mind a gyakorlati megközelítés teret kap munkája során. Ennek eredményeként a járványügyi, gazdasági, társadalmi, szociális stb. kockázatok megállapításán túl azok csökkentési, mérséklési, megelőzési lehetőségeit is részletesen meghatározzák, arról közvetett módon, írásbeli összefoglalókkal folyamatosan tájékoztatva az egészségügyi minisztert is.

Az osztrák döntéshozók - ezen konklúziókra is figyelemmel - több törvényt is elfogadtak, amelyek széles körben tartalmaznak módosításokat ${ }^{79}$ a jogrendszer olyan alaptörvényeit érintően, mint például az állampolgársági, a közigazgatási bírósági vagy a telekommunikációs törvény. 2020. február 28-tól a különböző miniszteri rendeletek ${ }^{80}$ illetve Covid-19-törvények ${ }^{81}$ a pandémia megelőzési és kezelési igényének megfelelően rendelkeztek például a kereskedelmi vállalkozások múködésének korlátozásáról, illetve bezárásáról, a személyszállításról, a korona-segélyalapról, a válságkezelési alap (COVID-19-FondsG) létrehozataláról ${ }^{82}$ csakúgy, mint például a beutazásról vagy a korábbi korlátozó intézkedések enyhítéséről. A jogszabályok érintették az élet szinte minden területét - így például a gazdasági kamarákról szóló törvény módosítása elsősorban az akadálymentes múkködés feltételeit teremtette meg.

Szilárd határa a jogkorlátozó rendelkezéseknek, hogy azoknak szigorúan meg kell felelniük a járványhelyzet megelőzése és kezelése szempontjából vizsgált szükségesség és arányosság kritériumainak. Erre jó példát jelent a kijárási tilalom alakulása. Míg a járvány kezdetén országos kijárási tilalmat rendelt el a szövetségi kormány, amely szerint az állampolgárok az otthonukat csak élelmiszer-vásárlás, illetve a rászoruló emberek ellátása céljából hagyhatták el, az éttermek, bárok, kávézók és iskolák bezárásra, minden összejövetel, tömeges rendezvény betiltásra került, ez május elseje után megszúnt. Már nem állt fenn a két

78 Járványügyi tv. 3a. \$.

79 A jogszabályokat és azok gyakorlati kérdéseit tekinti át folyamatosan frissített tartalommal: Resch, 2020.

80 Így például a szövetségi szociális, egészségügyi, ápolási és fogyasztóvédelmi miniszter rendeletét az Ausztriába való belépésről a SARS-CoV-2 visszaszorításával kapcsolatban vagy a Covid-19 elterjedése elleni küzdelem érdekében hozott intézkedések enyhítéséről (részletesebben: FRA, 2020b).

81 2. COVID-19-Gesetz, 3. COVID-19-Gesetz, 5. COVID-19-Gesetz.

82 Bundesgesetz über die Errichtung des COVID-19-Krisenbewältigungsfonds (COVID-19-FondsG). Hasonlóképpen sikeres kezdeményezés volt a Korona rövid munkaidejú (Kurzarbeit) foglalkoztatást támogató program, lehetővé téve az eredeti nettó jövedelem 80-90\%-ának kézhezvételét csökkent munkaidő mellett is (FRA, 2020a, 25. o.). 
kritérium egy ilyen szintû alapjog-korlátozáshoz, hiszen a kis üzletek április közepi megnyitása nem vezetett a fertőzésszám megugrásához. Ezért ezt követően a mozgási szabadság korlátozásának a koronavírus-járvány megelőzése szempontjából szükséges és arányos mértéke az összejövetelek résztvevői számának maximum 10 fốben történő meghatározáaát vagy a minimális társadalmi távolság betartásának előirását indokolta. A második hullám újra indokolttá és arányossá tette a szigorúbb fellépést, így november 3-ával bevezették az éjszakai (20.00-06.00 óra) kijárási tilalmat, amely alól csak a rendeletben nevesített esetekben van kivétel.

Az alapjoggyakorlást szúkítő rendelkezések időbeli korláthoz kötöttek, amit tipikusan maguk a jogszabályok ${ }^{83}$ már hatálybalépésükkor tartalmaznak. Így például a Covid-19 terjedésének megakadályozását célzó ideiglenes intézkedésekről rendelkező szövetségi törvény 4. $\$$ (1) bekezdésében rögzíti, hogy a szövetségi törvény a kihirdetés napján lép hatályba, és 2020. december 31-én hatályát veszti. (Nem kizárt azonban a korlátozó intézkedések esetleges meghosszabbítása, mielőtt azok hatályukat vesztenék.)

A törvényességi kontroll számos formában fennáll, de az osztrák parlament nem gyakorol közvetlen ellenőrzést a Covid-19-törvény alapján a kormány által hozott egyedi intézkedések felett. ${ }^{84}$ Ennek hátterében az áll, hogy a rendeletekben rögzített alapjog-korlátozások bevezetéséért, végrehajtásáért, illetve megszüntetéséért továbbra is az adott jogterületért felelős szövetségi és tartományi minisztériumok (illetve áttételesen a végrehajtásban érintett egyéb hatóságok) felelnek. A parlament közvetett ellenőrzési joga azonban fennáll. Ez különösen arra fókuszál, hogy a kormány nem lépi-e túl részben a Covid-19-törvényben, részben a Járványügyi tv.-ben rögzített hatásköreit. Minthogy a demonstrációkat és más gyúléseket nevesítetten nem sorolta fel a Covid-19-intézkedésekről szóló rendelet egyik módosítása sem, így ezekre is a többi szabadtéri rendezvényre irányadó általános szabályok vonatkoznak. Ebből adódóan, amikor például 2020 őszén a koronavírus-tagadók (Corona Leugner) felvonulást szerveztek a korlátozó intézkedések ellen, Bécs rendőrfőnöke hiába kérte ${ }^{85}$ az egészségügyi hatóságokat annak betiltására, erre végül a magas járványügyi kockázatok ellenére sem került sor. A döntés értelmében ugyanis a tiltás jogi alapja nem állhatott fent, mert nem lehetett előzetesen tudni, hogy a demonstrálók betartják-e majd a maszkviselésre és a távolságtartásra vonatkozó előírásokat; azaz egészségük ténylegesen veszélyben lesz-e, vagy sem. ${ }^{86} \mathrm{~A}$ szükségesség és arányosság követelménye konkrét jogszabályi rendelkezések ${ }^{87}$ kapcsán is fennáll.

83 Például a Covid-19 védelmi intézkedésekről szóló rendelet (COVID-19-SchuMaV).

84 Atanassov et al., 2020, 3. o.

85 Lásd az ORF tudósítását: https://wien.orf.at/stories/3073612/ (Letöltve: 2020. november 10.).

86 A részt vevő körülbelül 1500 ember túlnyomó többsége egyébként sem a távolságtartásra, sem a maszkviselésre vonatkozó előírásokat nem tartotta be.

87 Így a Covid-19-korlátozásokat enyhítő rendelet (COVID-19-Lockerungsverordnung - COVID-19-LV) rendezvényeket érintő 10. \$ (13) bekezdése értelmében azon résztvevőkkel szembeni intézkedés alkalmazásától, akik megszegik a maszk viselésére vonatkozó szabályokat, tartózkodni kell, amennyiben a törvényes állapot enyhébb eszközökkel is helyreállítható, vagy ha az intézkedések aránytalanok lennének. 
Számos rendelkezés kapcsán a viták különösen erős politikai színezetet kapnak (például médiafinanszírozás), aminek hatására a Riporterek Határok Nélkül sajtószabadság-rangsorában két helyet visszaesett az ország..$^{88} \mathrm{~A}$ külföldi újságírók kormányzati sajtótájékoztatókon való részvételi lehetőségének korlátozása kapcsán az Európai Unió határozott rosszallása is megfogalmazódott. ${ }^{89}$ Sokan azt emelték ki, hogy a jelenlegi osztrák kormánynak „az üzenetek ellenőrzése" a legfontosabb prioritás, míg a „független és szabad média, amely kritikus jelentést készít és nyomon követi a kormány munkáját, természetesen nem kívánatos".

A pandémia által generált állami reakciókat ${ }^{90}$ érintő heves kritikák ${ }^{91}$ egyrészt a reagálás minőségét, másrészt a konkrét beavatkozási formákat, a döntéshozatal mikéntjét és annak tartalmi elemeit állították a középpontba.

Előbbire jó példa az osztrák sícentrumban, Ischgl településén kitört koronavírus-járvány kezelését vizsgáló, független szakértői bizottság megállapítása. A tiroli régiót mélyen megrázó történet elemzése kapcsán megállapítást nyert a hivatalnokok lassú reakciója, gyenge kommunikációja, „súlyos téves számításaik”, és az ebből adódó rossz kríziskezelési válaszok sora. ${ }^{92}$ Figyelemmel arra, hogy a településről pánikszerúen távozó külföldi turisták okán több ezer fertőzött személy árasztotta el Európát, ezért az osztrák ügyészség nyomozást folytat - gyanúsítottként - egy osztrák és három német személy ellen.

Számos negatív vélemény illeti a konkrét beavatkozási formákat. Így - miközben a nemzetek igyekeznek korlátozni ${ }^{93}$ a vírus terjedését - olyan technológiákhoz is folyamodnak (például az érintkezéseket nyomon követő applikációo ${ }^{94}$ lehetősége), amelyek jelentős adatvédelmi aggályokat ${ }^{95}$ vetnek fel. (De ezen túl is: például a Stopp-Corona-App megjelenésekor a közbeszédet a programot használni nem kívánókkal szembeni negatív attitúd uralta; gyakorlatilag előre megbélyegezték őket, mint olyan személyeket, akik semmit sem tesznek a vírus terjedésének megakadályozása érdekében.)

A döntéshozatal mikéntje és annak tartalmi elemei is a vizsgálatok részét képezték, függetlenül azok pozitív céljától. Az alapvető jogokat korlátozó intézkedések, valamint a jogalkotási eljárások egy-két nap alatt történő „felpörgetése”, ami nem igazán ad teret komoly parlamenti megfontolásnak, több negatív véleményt ${ }^{96}$ generált. Részben ezzel összefüg-

88 Lásd a Kurier cikkét:https://kurier.at/politik/inland/kritik-an-einschraenkungen-der-pressefreiheit-geradein-der-krise/400830557 (Letöltve: 2020 . november 11.).

89 „Nagyon aggasztó, hogy néhány országban a Covid-19-pandémiát ürügyként használják a sajtószabadság jogellenes korlátozásainak bevezetésére." (Lásd a DerStandard cikkét:www.derstandard.at/story/2000117254401/ eu-kommission-warnt-vor-beschraenkung-der-pressefreiheit [Letöltve: 2020 . november 1.].)

90 Bradley et al., 2020.

91 Lásd erről részletesebben: Bennoune, 2020.

92 Lásd a Deutsche Welle hírét: www.dw.com/en/commission-blames-austrian-government-for-poor-handlingof-ischgl-coronavirus-outbreak/a-55251063 (Letöltve: 2020. november 11.).

93 Bradley, et al., 2020, 576. o.

94 Wiese, 2020.

95 Lásd a Wiener Zeitung honlapját: www.wienerzeitung.at/verlagsbeilagen/digitale-republik/2057405-Ueberwachung-als-neue-Normalitaet.html (Letöltve: 2020 . november 11.).

96 Gamper, 2020. 
gésben az is megállapításra került, hogy Ausztriában hiányzik az alkotmánybíróságon keresztül megvalósuló ideiglenes jogi védelem. Azaz nincs olyan mechanizmus, amely lehetôvé tenné, hogy a tervezett törvényeket már a jogalkotási folyamat során ellenőrizze az alapvető jogoknak való megfelelés szempontjából.

Bár a Covid-19 lehetőséget kínálna az emberi jogok elérhetőségének szélesítésére, mélységének megerősítésére a társadalom marginalizálódott csoportjai (például szabadságvesztésüket töltők) számára is, ezek a jogszabályok úgynevezett „ad-hocizmusban” szenvednek - hiányzik belőlük a komplex látásmód, a rendszerben gondolkodás, így sokkal kevésbé képesek szolgálni ezen fokozottan kiszolgáltatott helyzetú személyek jogainak védelmét a pandémia idején. A veszély nagy, hiszen „mind a világjárvány, mind a kormány erre adott válaszai szinte minden nemzetközileg elismert emberi jogot fenyegetnek" ${ }^{97} \mathrm{Az}$ olyan, a járvány elterjedésének korlátozása céljából elengedhetetlen megoldások, mint a társadalmi távolságtartás, a maszkviselés és számos más tevékenység korlátozása, az emberi interakció szinte minden aspektusára kihatnak, ${ }^{98}$ és a figyelem középpontjába emelik a beavatkozás arányosságát, időlegességét, indokoltságát és utóbbi folyamatos igazolását. Így például a gyülekezési jog korlátozása a 2020 tavaszi „Vásárolni igen, tüntetni nem!” szlogen alapján komoly ellenérzést váltott ki. Ha a - nem vitathatóan - fontos gazdasági érdekek miatt megnyitott boltokban volt lehetőség vásárolni, akkor aligha volt magyarázható az összejövetelek mint a gyülekezési szabadság megtestesülései tilalma.99

A megfogalmazott aggályokat - függetlenül a Covid-jogszabályok megszületésének támadhatóságától - részben enyhíti a sunsetklauzulák alkalmazásával garantált és programozott „elmúlásuk”. Másrészt a transzparencia és az áttekinthetőség, indokoltság igazolhatósága érdekében életre hívták és elérhetővé tették ${ }^{100}$ az úgynevezett „korona-jelzőlámpát” (Corona-Ampel), a Korona(vírus)-bizottság kvalitatív és kvantitatív forrásokra támaszkodó területi epidemiológiai kockázatjelzését. A civil-, politikai, szakértői kontroll intenzitását mutatja, hogy például a Stop-Corona-App kapcsán az FPÖ politikusai azzal vádolták meg a kormányt, hogy "totalitárius kém- és megfigyelóállammá akarja építeni Ausztriát”. ${ }^{101}$ Az Osztrák Szövetségi Ügyvédi Kamara ${ }^{102}$ a koronapandémia miatt folyamatos és valós idejű

97 Lásd erről részletesebben: Neha, 2020.

98 Lásd erről részletesebben: Bennoune, 2020.

99 Lásd a Wiener Zeitung riportját: www.wienerzeitung.at/verlagsbeilagen/digitale-republik/2057986-Coronaund-Grundrechte-Shopping-ja-demonstrieren-nein.html (Letöltve: 2020. november 1.).

$100 \mathrm{Az}$ információk elérhetők a Corona-Ampel honlapról. Elérhető: https://corona-ampel.gv.at/karte-coronaampel/.

101 Lásd az APA-OTS beszámolóját: www.ots.at/presseaussendung/OTS_20200404_OTSo028/fpoe-kickl-sobotka-will-oesterreich-zum-totalitaeren-ueberwachungsstaat-umbauen (Letöltve: 2020. november 11.).

102 Az Osztrák Ügyvédi Kamarai Nap (ÖRAK) COVID-19-jogszabály-gyüjteménye a honlapjáról érhető el: www. rechtsanwaelte.at/Covid-19/gesetze-und-verordnungen/bundesgesetze/. 
online oldalt ${ }^{103}$ múködtet, kritikai támogatással. ${ }^{104} \mathrm{~A}$ szakmai folyóiratokban is intenzív a diszkusszió, ${ }^{105}$ például az oltások kötelezővé tételét érintően. ${ }^{106}$

A pandémia által generált helyzetet kísérő erős kritikai attitûd lecsapódik az osztrák alkotmánybíróság munkájában is. A beadványok száma jelentősen megnőtt a korábbi, migrációs krízis által uralt, hasonló kormányzati intézkedéseket kiváltó időszakhoz képest. Így a jogi felülvizsgálatok körében ${ }^{107}$ csak 2020-ban 38 döntés született (például a szolgálati jogról); ebből 13 érintett valamely Covid-19-jogszabályt. Az egyéni indítványra indult ügyek kezdetben inkább a visszatérés utáni karanténkötelezettség értelmezéséről, majd a létszáma távolságtartási, az utazási korlátozások jogalapjáról, illetve a jogkorlátozások arányosságáról, szükségességéről, újabb döntéseiben pedig azok indokoltságáról szóltak.

A határozatok egy része azzal kapcsolatban született, hogy az Ausztriába való visszatérés utáni karanténkötelezettség hogyan értelmezendő, a negatív Covid-teszt mennyiben váltja ki azt, és hogy ennek törvényi szintú eltérő szabályozása az alkotmányban rögzített alapjogokkal szembehelyezkedik-e. Ilyen például a V 432/2020-6 számú döntést megalapozó beadvány, amely a Szövetségi Szociális, Egészségügyi, Ápolási és Fogyasztóvédelmi Minisztérium a szomszédos országokból történő beutazással kapcsolatos intézkedéseket módosító miniszteri rendeletének ${ }^{108}$ alaptörvényben rögzített alapjogba való ütközését kérte kimondani, ${ }^{109}$ amit 2020. június 16-án az alkotmánybíróság elutasított. Más beadványok a szövetségi miniszter a Covid-19-hez kapcsolódó egyéb rendeletét ${ }^{110}$ támadták, többek között azon módosító tételt, amely szerint „egy kiscsoportban legfeljebb hat csapatjátékos, állandó személyi összetétellel [...] vehet részt”, illetve, hogy „a csapat játékosai, edzőnői és edzői, trénernői és trénerei között legalább két méter távolságot kell tartani”. Az indítványok - más okok miatt (például legitimáció) - itt is elutasításra kerültek. ${ }^{111}$ A létszámmal, illetve a távolságtartással kapcsolatos kérdéseken túl más beadvány az utazási korlátozásokat érintette. 2020. július 14-i határozatában elfogadta ugyanakkor az alkotmánybíróság ${ }^{112}$ annak az állampolgárnak a beadványát, s így a Covid-19-intézkedésekről szóló rendelet 1., 2., 4. és 6. \$-át

103 A Korona: Aktuális információk az igazságszolgáltatás és az ügyvédség számára címú tájékoztató oldal a Szövetségi Ügyvédi Kamara (BRAK) honlapján található.

104 Lásd a Szövetségi Ügyvédi Kamara honlapját: https://brak.de/zur-rechtspolitik/newsletter/nachrichten-ausberlin/2020/sondernewsletter-v-242020/ortung-von-mobiltelefonen-brak-aeussert-sich-kritisch/ (Letöltve: 2020. november 1.).

105 Fucik et al., 2020, 337. o.

106 Lásd erről részletesebben: Parlamentskorrespondenz Nr. 1378 vom 07. Dezember 2020.

107 Lásd erről az alkotmánybíróság honlapját. Kiválasztott döntések elérhetô: www.vfgh.gv.at/rechtsprechung/ Ausgewaehlte_Entscheidungen.de.html.

108 A szövetségi szociális, egészségügyi, gondozási és fogyasztóvédelmi miniszter rendelete a szomszédos országokból történő beutazással kapcsolatos intézkedéseiről szóló rendelet módosításáról (BGBl. II Nr. 195/2020)

109 Verfassungsgerichtshof V 432/2020-6 (16. Juni 2020.).

110 A szövetségi szociális, egészségügyi, gondozási és fogyasztóvédelmi miniszter rendelete a Covid-19-intézkedéscsomagról szóló törvény 2. \$1. cikkének megfelelően (BGBl. II Nr. 98/2020).

111 Verfassungsgerichthof V 401/2020-13, V 420/2020-9 döntései (15. Juni 2020).

112 Herzig, 2020. 
is hatályon kívül helyezte, aki grazi lakásából bécsi otthonába a korlátozó intézkedések miatt nem tudott tömegközlekedés használatával eljutni. Az alkotmánybíróság ez esetben a döntés alapját abban ragadta meg, hogy bár a Covid-19 terjedésének megakadályozása érdekében lehet alapjog-korlátozó intézkedést hozni, de az alkotmány által garantált mozgásszabadságot és egyéb polgári jogokat ennek meghatározása során a lehetőségekhez mérten, a legszélesebb körben tiszteletben kell tartani. A konkrét esetben ez hiányzott, azaz nem valósult meg az arányosság és indokoltság kritériuma. Az újabb, augusztusi rendeletmódosítás is fenn kívánta tartani a nyilvános helyekre való bejutás általános tilalmát - noha az alkotmánybíróság kifejezetten megjegyezte, hogy ilyen korlátozás csak megfelelő ideiglenes, személyes és objektív korlátozások mellett engedélyezhetô. Újabb döntéseiben ${ }^{113}$ az alkotmánybíróság követte nyári (2020. július 14-i) gyakorlatát, és számos rendelet alkotmányellenességét állapította meg - bár részben eltérő indokolással. Így jogellenes például több, 2020 tavaszán életbe lépett Covid-19-intézkedés, különösen az éttermekbe és a nem benzinkúthoz csatlakozó, önálló autómosókba való bejutás tilalma, a vendéglátóhelyek vendégszámának korlátozása, a távolságtartás elrendelése az éttermi szolgáltatást nyúitó szolgáltatók tekintetében. A döntések legkésőbb 2020. december 31-én lépnek hatályba. A jogellenesnek elismert rendelkezés esetében az alkotmánybíróság álláspontja szerint a benyújtott iratokból nem lehetett megállapítani, hogy az egészségügyi miniszter mely ténybeli körülmények alapján tartotta azokat szükségesnek és indokoltnak. Ez a tény azonban sérti a Covid-19-intézkedésekről szóló törvényben vagy a Járványügyi tv.-ben meghatározott alapelveket.

\section{4. Összegzés}

Az osztrák és a magyar különleges jogrendi szabályozás mind szellemiségében, mind jogtörténeti előzményeiben, mind jogtechnikai megoldásaiban jelentősen eltér egymástól. Ez annak ellenére igaz, hogy a két ország létének meghatározott időszakában azonos szövetségi rendszeren belül létezett - legyen az a Habsburg Birodalom, az Osztrák-Magyar Monarchia vagy épp az Európai Unió. Sikeres kommunikációs stratégiájának eredményeként a 2. világégés után, a Német Birodalomhoz való korábbi erős elköteleződési szándék ellenére az okkupációs elmélet került elfogadásra, lehetôvé téve ezzel az alkotmányos kontinuitást. A hatályos osztrák alkotmány így az 1920-as, alapjogi elemeiben az 1867-es alkotmányt, más vonatkozásokban az 1929-es alkotmánymódosítást foglalja magában, s továbbviszi a különleges jogrend sajátos megközelítését.

Noha mindkét ország jogrendszere eleget tesz az Európai Unió és egyéb nemzetközi dokumentumok elvárásainak mind garanciális, mind jogállamisági szempontból, a szabályozás szintjében és részletességében eltérő utat követnek. Ausztria alkotmányos szinten

113 Elérhető: www.vfgh.gv.at/medien/Entscheidungen_Oktober-Session.php (Letöltve: 2020. november 11.). 
(B-VG) nem szabályozza részletesen a különleges jogrendre vonatkozó ismérveket, s bár az elmélet a veszélyhelyzetek négy nagy csoportját ismeri - háborús helyzet, felkelés és lázadás, katasztrófák és ellátáshiány -, ezek közül az első kapcsán találhatunk részletesebb rendelkezést a $\mathrm{B}-\mathrm{VG}-$ ben. ${ }^{114} \mathrm{Az}$ alaptörvény nem rendel kifejezett hatáskört ${ }^{115}$ a kormánynak, a szövetségi elnöknek vagy bármely más szervnek arra, hogy hivatalosan meghatározza a válság, válsághelyzet fennállását. Különleges jogrendi jogalkotási joggal - az alkotmány értelmében - a szövetségi elnök rendelkezik, amellyel háború, természeti katasztrófa és más vészhelyzetek esetében a kormány javaslatára élhet. Ezen jog gyakorlását azonban komplex kritériumrendszer, azaz előzetes negatív (például a Nemzeti Tanács döntéshozatalának akadályozottsága), előzetes pozitív (például a szövetségi kormány ellenjegyzése), tartalmi szúkítő (például nem érintheti az alkotmányt) és utólagos (például haladéktalan beterjesztés a Nemzeti Tanács elé) feltétel bástyázza körbe, szigorú előzetes és utólagos kontrollt alkotva.

A szövetségi berendezkedésből adódóan a döntési és végrehajtó hatalom a szövetségi és tartományi hatóságok, illetve - történelmi okok miatt - az alkotmány és az egyéb törvények között megoszlik. A releváns alapjog-korlátozó rendelkezések elrendelhetőségének kritériumait az olyan jogszabályok tartalmazzák, mint például a biztonsági rendőrségről vagy a honvédelemről szóló törvény, megosztva a döntési jogokat az illetékes minisztériumok és a szövetségi kancellária között. A legélesebb szakmai kritikák ${ }^{116}$ logikailag következetlennek („logische Inkonsequenz”), a probléma gyökerénél való kezelését gátlónak („ein Notstand kaum an der Wurzel geheilt werden könnte") tekintik a vészhelyzeti szabályozás mikéntjét és formáját is. „[M]íg az alkotmány részleges és szétszórt intézkedéseket biztosít a szükséghelyzet kezelésére, Ausztria nem rendelkezik tényleges vészhelyzeti alkotmánnyal." ${ }^{{ }_{117}} \mathrm{Ez}$ - a példaértékủ krízisstratégia és intézményrendszer ellenére - különösen az egyéb veszélyhelyzetekhez képest kevéssé súlyosnak értékelt menekültügyi válság rendezésével összefüggő nehézségek okán erősödött fel, strukturális változtatásokat generálva (Biztonsági Kabinet).

Ezen elméleti megközelítést követi a koronavírus-járvány kezelése kapcsán is az osztrák állam. Figyelemmel arra, hogy az osztrák parlament mindvégig múködött, így nem került sor sem a különleges jogrendet érintő veszélyhelyzeti kormányzás, sem rendkívüli állapot kihirdetésére, sem sürgősségi rendeletek elfogadására. ${ }^{118}$ Élt ugyanakkor a kormány mindazokkal a jogszabályi felhatalmazásokkal, amelyek lehetővé tették alapjog-korlátozó rendelkezéseket megalkotását. Ezek kapcsán azonban fontos - akár az alkotmánybíróság döntését is kiváltó - kritérium a szükségesség, arányosság, indokoltság, hatékonyság és különösen

114 B-VG 9a. és 79. cikk.

115 Szemben például a német alaptörvény 80a. cikkében rögzített kétharmados szavazati kötelezettséggel.

116 Pernthaler és Ermacora gondolatait idézi Reindl-Krauskopf et al., 2016, 119. o.

117 Ermacora, 1998, 409. o.

118 European Training and Research Centre for Human Rights and Democracy: Coronavirus pandemic in the EU - Fundamental Rights Implications. Country: Austria. ETC Graz, 3 November 2020. European Union Agency. 
az időbeli korlátozottság megléte. Ez utóbbi konkrét időpontok (sunsetklauzulák) formájában kerül meghatározásra a Covid-19-rendeletekben, amelyek szükség esetén meghosszabbíthatók. A törvényességi kontroll tehát számos formában fennáll, de az osztrák parlament nem gyakorol közvetlen ellenőrzést a Covid-19-törvény alapján a kormány által hozott egyedi intézkedések felett. ${ }^{119}$

A szakmai források ${ }^{120}$ közül több ${ }^{121}$ szerint az alkotmányban rögzített különleges jogrendi rendelkezések, a szövetségi elnök sürgősségi rendeletalkotási joga kvázi „holt jognak” tekinthető, hiszen mind eljárási, mind tartalmi korlátozottsága okán (B-VG 18., 97. cikkelyei) célszerú alkalmazása szinte lehetetlen. Bár a terrorizmus nemzetköziesedése, illetve felerôsödése - különösen 9/11 - után számos szervezeti változtatást foganatosított az állam, különösen a migrációs válsággal kapcsolatos éles helyzet mutatta meg azt, hogy szükség van további lépésekre.

\section{Irodalomjegyzék}

Atanassov, N., Dalli, H., Dumbrava, C., Eckert, G., Jurviste, U., Radjenovic, A., Voronova, S. (2020) States of Emergency in Response to the Coronavirus Crisis: Situation in Certain Member States II. (European Parlament Briefing). Elérhető: www.europarl.europa. eu/RegData/etudes/BRIE/2020/651914/EPRS_BRI(2020)651914_EN.pdf (Letöltve: 2020. november 11.)

Augustin, J. (2016) Ausnahmezustand. Die österreichische Notstandsverfassung aufdem Prüfstand [Online]. Elérhető: www.publiclaw.at/pl/images/stories/schriftenreihe\%202-2016\%20 augustin.pdf (Letöltve: 2020 . november 11.)

Bennoune, K. (2020) '„Lest We Should Sleep”: COVID-19 and Human Rights', American Journal of International Law, 114(4), 666-676. o.

BRAdley, C. A., HELfER, L. R. (2020) 'Introduction to "The International Legal Order and the Global Pandemic"', The American Society of International Law, 114(4), 571-577. o.

Bundesministerium für Inneres (2013) Staatliches Krisen-und Katastrophenschutz-Management. Rechtliche und Organisatorische Grundlagen. 2. kiadás. Wien: BMI

ERMACORA, F. (1998) Österreichische Verfassungslehre. Taschenbuch. 1. kiadás. Wien: Verlag Österreich

FRA (2020a) Coronavirus Pandemic in the EU - Fundamental Rights Implications. Luxembourg: Publication Office of the EU

FRA (2020b) Coronavirus Pandemic in the EU - Fundamental Rights Implications. Country: Austria. European Training and Research Centre for Human Rights and Democracy.

119 Atanassov et al., 2020, 2-3. o.

120 Augustin, 2016, 100. 0.

121 Mathis Fister, Stefan L. Frank, Bernhard Raschauer gondolatait hivatkozza Augustin, 2016, 100. o. 
[Online]. Elérhetô: https://fra.europa.eu/sites/default/files/fra_uploads/austria-reportCovid-19-april-2020_en_0.pdf (Letöltve: 2020. november 11.)

Fucik, R., LeHofer, H. P. (2020) 'Die nächsten drei COVID-19-Gesetze', Österreichische Juristen Zeitung, 2020/8, 337-340. 0 .

GAMPER, A. (2020) Corona und Verfassung [Online]. Elérhető: www.uibk.ac.at/oeffentlichesrecht/100-jahre-b-vg/corona-und-verfassung.html (Letöltve: 2020 . november 11.)

JACHS, S. (2011) Einführung in das Katastrophenmanagement. 1. kiadás. Hamburg: Tedition HINGHOFER-SZALKAY, S. G. (2019) Verfassungsrechtsentwicklung aus rechtstatsächlicher Perspektive. 1. kiadás. Heidelberg: Springer

HeRzIG, R. (2020) Constitutional Court Overrules COVID19 Restrictions [Online]. Elérhető: www. internationallawoffice.com/Newsletters/Healthcare-Life-Sciences/Austria/PreslmayrAttorneys-at-Law/Constitutional-Court-overrules-COVID-19-restrictions (Letöltve: 2020. november 11.)

KeLEMEN, R. (2019) 'Az Alaptörvény szükségállapot-szabályozásának kritikai áttekintése az egyes európai uniós tagállamok alkotmányainak figyelembevételével' in Bartkó, R. (szerk.) A terrorizmus elleni küzdelem aktuális kérdései a XXI. században. 1. kiadás. Budapest: Gondolat Kiadó

KojA, F. (1979) Der Staatsnotstand als Rechtsbegriff. 1. kiadás. Wien: Pustet

Maróti, D. (2017) 'A Második Osztrák Köztársaság az átmeneti időszakban', Polgári Szemle, 13(1-3), 392-406. o.

NeHA, J. (2020) 'Pandemics as Rights-Generators', The American Society of International Law, 114(4), 677-686. o.

Reindl-Krauskopf, S., Salimi, F., Kraml, B., Schulev, E., Scharler, S-M., Pekler, J. (2016) Resilienz des Rechts in Krisenzeiten. 1. kiadás. Wien: Bundesministeriums für Inneres

Resch, R. (szerk.) (2020) Das Corona-Handbuch. Österreichs Rechtspraxis zur aktuellen Lage. 1. kiadás. Wien: Manz

SEIDL, C. (2016) Bundesheer wird gestärkt, der Bundeskanzler nicht [Online]. Elérhető: www. derstandard.at/story/2000045002069/bundesheer-wird-gestaerkt-der-bundeskanzlernicht (Letöltve: 2020 . november 11.)

Staudigl-Ciechowicz, K. (2018) 'Das Kriegswirtschaftliche Ermächtigungsgesetz 1917', Beiträge zur Rechtsgeschichte Österreichs, 2018/2, 274-293. o.

SzABó, I. (2010) Ausztria államszervezete 1918-1955. 1. kiadás. Budapest: PPKE JÁK

TilL, Sz. (2019) 'Különleges jogrend' in Jakab, A., Fekete, B. (szerk.) Internetes Jogtudományi Enciklopédia. Elérhető: http://ijoten.hu/szocikk/kulonleges-jogrend (Letöltve: 2020. december 13.)

WiESE, J. (2020) Bilanz nach einem halben Jahr „Stopp Corona“-App [Online]. Elérhető: https:// help.orf.at/stories/3202229/ (Letöltve: 2020. november 9.)

WiMMER, T., MÜLLER, N. (2018) Wirtschaftsrecht. 3. kiadás. Wien: Verlag Österreich

Wissmann, H. (szerk.) (2015) Europäische Verfassungen 1789-1990. 1. kiadás. Tübingen: Mohr Siebeck 